\title{
A Case of Schwannoma Arising from the Sphenoid Sinus
}

\author{
A Young Choi ${ }^{1}$, Ji Sun Kim ${ }^{1}$, Sang Won Yoon ${ }^{1}$ and Young Ok Hong ${ }^{2}$ \\ ${ }^{1}$ Departments of Otorhinolaryngology, ${ }^{2}$ Pathology, Eulji University College of Medicine, Seoul, Korea
}

\section{접형동에 발생한 신경초종 1 예}

최아영 ${ }^{1} \cdot$ 김지선 $^{1} \cdot$ 윤상원 $^{1} \cdot$ 홍영옥 $^{2}$

을지대학교 의과대학 을지병원 이비인후과학교실, ${ }^{1}$ 병리학교실 ${ }^{2}$

\author{
Received August 27, 2010 \\ Revised November 15, 2010 \\ Accepted December 7, 2010 \\ Address for correspondence \\ Ji Sun Kim, MD, PhD \\ Department of Otorhinolaryngology, \\ Eulji University College of Medicine, \\ 14 Hangeulbiseok-gil, Nowon-gu, \\ Seoul 139-872, Korea \\ Tel $+82-2-970-8276$ \\ Fax $+82-2-970-8275$ \\ E-mailvvicky96@eulji.ac.kr
}

Schwannomas are neurogenic tumors that arise from the Schwann cells of the nerve sheath. Although up to $45 \%$ of all schwannomas occur in the head and neck region, only $4 \%$ involve the nasal cavity and paranasal sinuses. A 56-year-old female presented with an incidentally discovered lesion in the left posterior ethmoid and sphenoid sinuses on the brain magnetic resonance imaging. Magnetic resonance imaging showed a well demarcated mass without bony destruction with isointensity in T1 and hyperintensity in T2 weighted scans. Eighteen months later, repeated computed tomography showed an enlargement of the mass with the erosion of the adjacent sinus wall and left vidian canal. She underwent an endoscopic mass removal, which revealed a pale yellowish, firm mass in the left posterior ethmoid and sphenoid sinuses. Final histopathology confirmed the diagnosis of a schwannoma. There has been no evidence of recurrence during the two-year follow-up.

Korean J Otorhinolaryngol-Head Neck Surg 2011;54:89-92

Key Words Sphenoid sinus - Schwannoma.

\section{서 론}

신경초종(schwannoma)은 신경막의 신경초세포(schwann cell)에서 기시하는 양성 종양으로 두개 내에 발생하 는 종양 중 약 $8 \%$ 정도를 차지한다. 신경초종은 모든 연령 에서 나타날 수 있으나 주로 20 대에서 50 대 사이에 발생하 며 $1 / 3,000$ 의 유병률을 보이고 남성보다 여성에서 $2 \sim 4$ 배 정도 많이 발생하는 것으로 보고되고 있다. ${ }^{1.2)}$ 비강 내에 발 생하는 신경초종은 매우 드물어 이와 관련된 연령, 성별, 인 종별 발생률에 대한 보고는 부족하다. ${ }^{3)}$ 전체 신경초종의 $25 \sim 5 \%$ 가 두경부에서 발생하고 있으나 비강이나 부비동 에서 기원한 경우는 $4 \%$ 정도로 보고되고 있으며,) 이 중 사골동이 가장 큰 비율을 차지하고 상악동, 비강, 접형동의

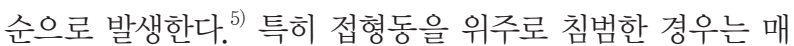
우 드물어 아직 국내 보고는 없고, 국외에서는 5 예가 보고되 고 있다. ${ }^{5,6)}$ 이에 저자들은 56 세 여자 환자에서 접형동에 발
생한 신경초종을 비내시경 접근법을 통해 치유하였기에 문 헌고찰과 함께 보고하는 바이다.

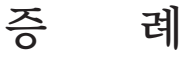

56 세 여자 환자로 건강 검진 시 시행한 뇌자기공명영상에 서 우연히 발견한 좌측 후사골동과 접형동의 병변을 주소로 내원하였다. 좌측 후사골동과 접형동에 위치한 병변은 경계 가 분명하였고 $\mathrm{T} 1$ 강조영상에서 중등도의 신호강도 $\mathrm{T} 2$ 강조 영상에서 고신호강도를 보였으며, $\mathrm{T} 1$ 조영증강 영상에서 내 부에 불균일하게 조영증강되는 소견을 보였다. 비내시경 소 견상 좌측으로 경도의 비중격 만곡증 외에 특이 소견은 관 찰되지 않았다. 부비동 전산화단층촬영 소견에서도 마찬가 지로 경도의 조영 증강 소견을 보이며, 주변의 골 소실이 동 반되지 않은 경계가 잘 형성된 병변이 관찰되었다. 내원 당 시 특이 증상은 호소하지 않았고 이학적 검사와 신경학적 
검사에서도 특이사항은 관찰되지 않았으며 영상학적 소견 상 주변구조의 압박 소견 없이 접형동 내에만 국한된 병변 으로 양성 소견을 보여 주기적인 전산화단층촬영을 통한 추 적 관찰을 계획하였으며 두통이나 복시 등의 증상 발생 시 즉시 내원하기로 하였다. 6 개월 간격으로 영상촬영을 통해 경과 관찰하던 중, 18 개월 째에 촬영한 전산화단층촬영상 접형동 내 병변의 크기가 증가하고 접형동 골벽과 익돌신경 관(vidian canal)에 소량의 미란이 확인됨에 따라(Fig. 1) 비내시경 접근법을 통한 종괴 제거술을 계획하였다. 수술 소견상 종괴는 좌측 후사골동과 접형동을 채우고 있었으며 피막에 둘러싸여 경계가 뚜렷하였고 주변 조직과의 유착이 거의 없어서 비교적 분리가 잘 되었다. 종물은 노란색을 띄 고 있었고 $3.6 \times 2.5 \times 1.2 \mathrm{~cm}$ 크기로 고무 정도의 경도를 보 였으며 분엽화되어 있었다(Fig. 2). 병리조직학적 검사상 종 양세포의 피막침윤, 핵의 다형성 및 세포분열은 없었으며 신 경초세포가 주위 결합조직과 잘 배열되어 있었고, 핵이 책 상 배열을 이루는 Antoni A와 세포배열이 느슨한 Antoni $\mathrm{B}$ 를 관찰할 수 있었다. 면역 조직화학 염색 결과 S-100 단 백에 양성인 신경초종에 합당한 소견을 보였다(Fig. 3). 수 술 직후 신경학적 증상은 호소하지 않았으며 술 후 2 년째 재 발의 증거 없이 외래 추적관찰 중이다.

\section{고 찰}

신경초종은 신경초세포에서 발생하는 양성 종양으로 서서 히 성장하고 주로 단발성으로 발생하며 피막에 잘 싸여진 종 괴의 형태를 보인다. 비강에 발생한 신경초종의 경우 술 후 신경학적인 기능저하를 일으키지 않는 경우가 많기 때문에 신경초종이 기원하는 신경을 확인하는 것은 어려우나, 보고 된 바에 따르면 삼차신경의 안분지 또는 상악분지, 자율신 경 분지 등에서 기원하는 것으로 알려져 있다. ${ }^{7,8)}$ 접형동에 분포하는 신경도 천장은 삼차신경의 안분지, 바닥은 삼차신 경의 상악분지, 접형동 점막의 감각은 접형구개신경절에서 기시한 부교감신경이 분포하고 있으며 모두 감각 신경으로 주변의 압박 소견 없이 접형동 내에만 국한된 경우에는 분 포지역의 감각저하 외에 특이증상을 유발하기는 어렵다. 또 한 신경초종은 신경을 둘러싸고 있는 신경초세포에서 기원 하며 그 내부에 신경구성성분을 포함하지 않기 때문에 대 부분의 경우 병소의 동통과 이물감 외에 특별한 초기 증상 은 없는 경우가 많으며, 크기가 서서히 증가하여 주변을 압 박하여 발생하거나 종괴의 괴사로 인해 갑작스럽게 크기가 커지는 경우 증상이 유발될 수 있다.

대표적인 증상으로는 비폐색, 비출혈, 비루, 후각감퇴, 국 소적인 안면부종 또는 통증 등이 있으며, 제 $3,4,5$ 번 뇌신
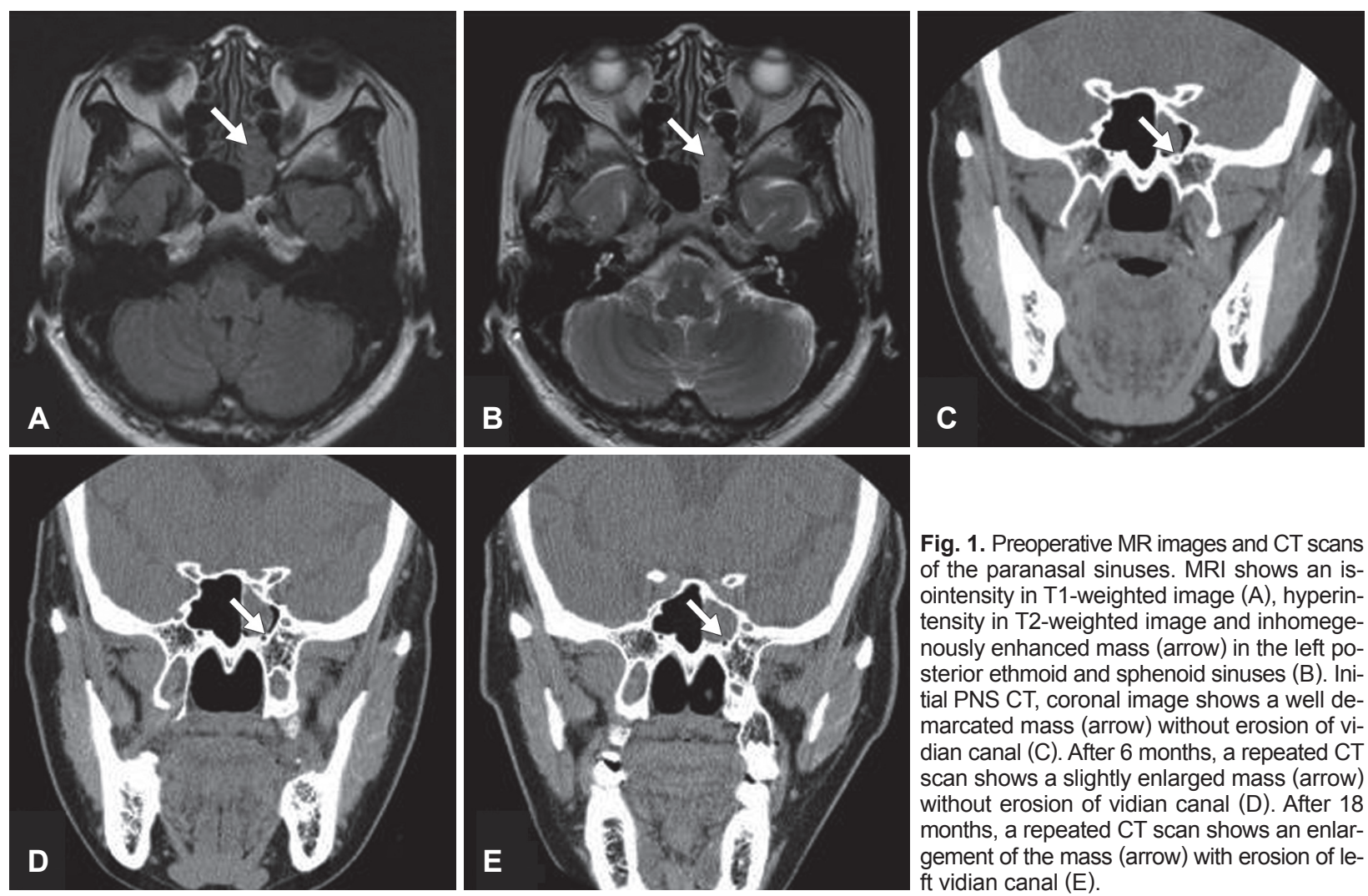

Fig. 1. Preoperative MR images and CT scans of the paranasal sinuses. MRI shows an isointensity in T1-weighted image (A), hyperintensity in T2-weighted image and inhomegenously enhanced mass (arrow) in the left posterior ethmoid and sphenoid sinuses (B). Initial PNS CT, coronal image shows a well demarcated mass (arrow) without erosion of vidian canal (C). After 6 months, a repeated CT scan shows a slightly enlarged mass (arrow) without erosion of vidian canal (D). After 18 months, a repeated CT scan shows an enlargement of the mass (arrow) with erosion of le$\mathrm{ft}$ vidian canal $(\mathrm{E})$. 
경을 침범한 접형동 신경초종 환자에서 복시, 후안구 통증, 전두부와 측두부의 통증을 호소한 예가 보고된 바 있다. ${ }^{6)}$ 발생한 부위별로 자주 동반되는 증상에 대해 살펴보면 사 골동이나 비강 내의 병변은 주로 비출혈을 유발하고, 상악 동과 접형동의 병변은 주로 통증을 유발하며 접형동에서 발생한 경우에는 주로 후안구통을 유발하게 된다. ${ }^{3)}$ 본 증례 에서는 병변의 크기가 주변을 압박할 정도로 크지 않고 부 비동 내에 국한되어 있어 특이 증상을 호소하지 않은 것으 로 생각된다. 수술 시 기원하는 신경은 확인할 수 없었으나 초기 영상 소견에서 좌측 접형동 바닥부위에는 빈 공간이 있는 점으로 미루어보아 천장부에서 기시하였을 가능성이 높으며 따라서 삼차신경의 안분지 또는 부교감신경에서 기 원하였을 것으로 추정된다.

수술 전 자기공명영상은 혼탁한 부비동내 병변의 원인을 추정하는 데 도움을 줄 수 있는데, 염증성 병변은 T2 강조 영상에서 고신호강도로, 종양은 중등도의 신호강도를 보여 폐색으로 인한 염증성 변화와 종양을 구별할 수 있다. ${ }^{9)}$ 일

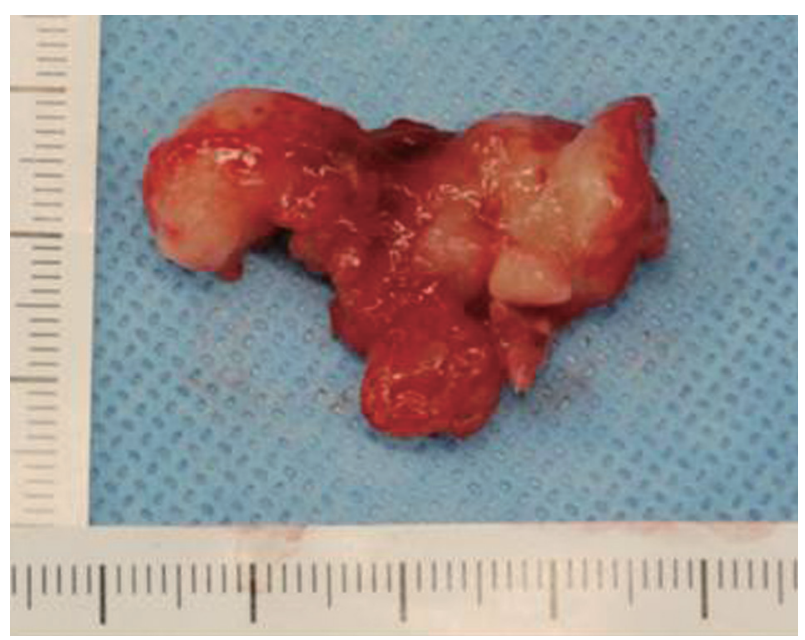

Fig. 2. The gross finding of surgical specimen shows a $3.6 \times 2.5 \times$ $1.2 \mathrm{~cm}$ sized, pale yellow, lobulating mass with firm consistency.
반적으로 신경초종은 자기공명영상촬영상 $\mathrm{T} 1$ 강조영상에서 종양의 세포 밀집 정도에 따라 Antoni A형에 해당되는 부 위는 중등도의 신호강도를 보이고 Antoni B형에 해당되는 부위는 저신호강도를 보이며, $\mathrm{T} 2$ 강조영상에서는 중등도의 고신호강도를 보인다. ${ }^{10)}$ 전산화단층촬영에서는 염증성 병변 과 종양성 병변이 모두 혼탁하게 보일 수 있으므로 두 병변 을 감별하기는 어렵다. 그러나 환자가 호소하는 증상을 고려 하여 부비동 혼탁을 보이는 동측의 감각저하, 안구증상이 동반되거나 혈액이 섞인 분비물이 관찰되는 경우에는 종양 성 병변을 염두에 두어야 한다는 보고가 있다. ${ }^{11}$

전산화단층촬영에서 양성과 악성 병변을 구별하는 방법 으로 전산화단층촬영의 영상을 bone window setting에서 관찰하는 방법이 있는데 골격 경계(skeletal margin)가 보 존되어 있다면 악성보다는 서서히 성장하는 양성을 시사한 다고 볼 수 있으며, ${ }^{2)}$ 신경초종은 전산화단층촬영상 이러한 양성 소견을 가지며 자기공명영상에서 비용종이나 점액낭종 보다는 고신호강도를 가지는 종괴로 표현될 수 있다. 감별해 야 할 다른 종양성 병변들로는 골화섬유종, 반전성 유두종, 편평세포암종, 선암종, 림프종 등이 있다. 골화섬유종은 전 산화단층촬영상 연조직과 골조직이 섞여 있는 경계가 분명 한 종괴로 관찰되며 자기공명영상에서는 $\mathrm{T} 1$ 에서는 중등도 의 신호강도, $\mathrm{T} 2$ 에서 중심의 섬유화된 부위는 고신호강도, 주변의 골화된 부위는 저신호강도를 보이는 것이 특징이다. 반전성 유두종은 주로 중비도에서 비강 측벽을 따라 발생하 며 전산화단층촬영상 불균일하게 조영증강이 되는 종괴로 나타나고 자기공명영상에서 $\mathrm{T} 1$ 에서는 중등도 또는 약한 고 신호강도, $\mathrm{T} 2$ 에서는 고신호강도로 관찰된다. 편평세포암종 은 전산화단층촬영상 불균일한 경계를 보이는 연부조직으 로 골파괴 소견이 동반되고 불균일하게 조영 증강되며 자기 공명영상 $\mathrm{T} 1$ 에서는 중등도의 신호강도, $\mathrm{T} 2$ 에서는 중등도 또는 고신호강도로 관찰된다. 선암종은 전산화단층촬영상
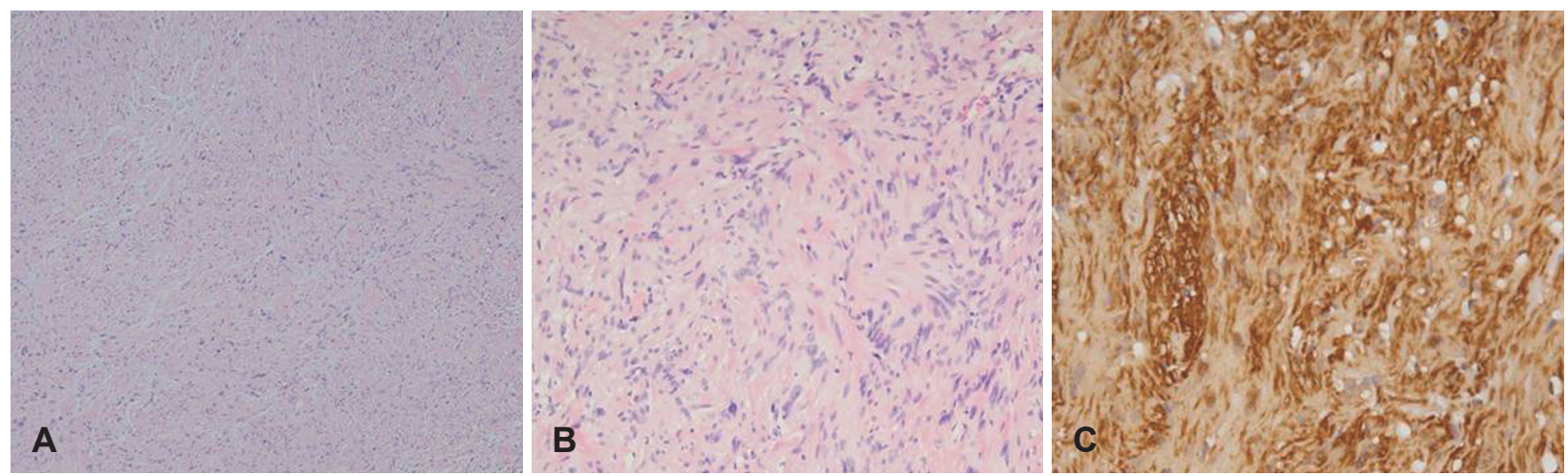

Fig. 3. Histologic features of schwannoma. The tumor shows biphasic pattern with hypercellular Antoni $A$ and hypocellular Antoni $B$ areas $(H \& E, \times 100)(A)$. Schwann cells show nuclear palisading in the center $(H \& E, \times 200)(B)$. The tumor cells are immunoreactive for S-100 protein $(H \& E, \times 400)(C)$. 
골조직의 재형성 또는 파괴 소견을 동반한 불균일한 조영증 강 소견을 보이며 자기공명영상 $\mathrm{T} 1$ 에서는 중등도의 신호강 도, $\mathrm{T} 2$ 에서는 중등도 또는 고신호 강도를 보인다. 림프종은 전산화단층촬영상 중등도로 균일한 조영증강을 보이는 종 괴로 관찰되며 자기공명영상 $\mathrm{T} 1, \mathrm{~T} 2$ 에서 중등도의 신호 강 도를 보인다. ${ }^{12)}$ 이처럼 영상학적 소견은 진단을 내리는데 충 분한 정보를 주지 못하는 경우가 많기 때문에 조직검사만이 확진을 할 수 있는 유일한 방법이다.

본 증례의 경우는 초기 영상에서 골미란이나 주변의 압박 소견이 관찰되지 않았으며 접형동내에 국한된 병변으로, 종 괴가 커지면 골팽창이나 골미란 소견이 먼저 관찰되기 때문 에 전산화단층촬영으로 추적 관찰하는 것이 보다 효과적이 라고 판단하였다. 또한 접형동 내에 국한되어 있으며 초기의 영상에서는 주변을 압박하는 소견이 보이지 않고 경계가 뚜 렷한 종괴 소견을 보여 양성 질환을 예측할 수 있었고, 추적 관찰 중 시행한 전산화단층촬영 결과 접형동의 병변에서 골 미란을 동반한 종괴의 성장 소견이 보여 수술적 제거술을 시행하였다.

증상이 없으며 영상 소견상 양성을 시사하는 일측의 접형 동에 국한된 병변은 염증에 의한 경우가 가장 흔하며 빈도 는 61 80\%로 보고되고 있다. ${ }^{13)}$ 염증을 시사하는 소견은 전산화단층촬영에서는 점막 비후 소견, 공기-액체층(airfluid level)이 관찰되거나 접형동 전체가 혼탁 소견을 보이 는 경우가 포함되며, 대개 골파괴는 관찰되지 않는다. 따라 서, 증상 없이 일측 접형동의 혼탁 소견만 관찰되는 경우는 염증에 준하여 6 8주간 항생제, 비강내 스테로이드 분무제, 점액용해제 등을 사용 후 변화가 없다면 수술하는 것이 권 유되고 있다. ${ }^{14)}$ 물론 환자가 신경학적 증상을 호소하거나 병 변의 진행이 의심된다면 가급적 빠른 시간 내에 수술적 치 료가 필요하다.

조직학적으로 종양 내는 두 가지 구별되는 세포구역으로 나뉘어지는데 Antoni A와 Antoni B가 이에 해당된다. Antoni $\mathrm{A}$ 는 방추형 세포가 규칙적인 배열을 보이는 부분으로 다발을 이루거나 울타리 배열 또는 소용돌이 배열을 이루는 데 밀집된 핵이 평행하게 배열된 부분을 Verocay body라고 부른다. ${ }^{3)}$ Antoni B는 방추형 세포가 거의 없으며 불규칙적 이고 느슨한 배열을 보이는 점액성 기질의 특성을 보이는 부분이다. S-100 단백은 신경계의 지지세포에 흔한 신경능 표지항원(neural crest marker antigen)으로 주로 신경 초세포나 멜라닌세포에서 기원한 종양에서 양성으로 나타 난다. Antoni B 조직과 악성화된 조직은 Antoni A 조직에 비해 상대적으로 신경초세포의 밀도가 낮기 때문에 S-100
단백의 발현 정도가 낮게 나타난다. ${ }^{15)}$

신경초종의 치료는 종괴가 방사선치료에 저항성이 있으므 로 수술적 절제술이 원칙이다. 일반적으로 양성 신경초종의 예후는 좋은 반면, 악성 변이(malignant variant)는 매우 공격적인 성향을 갖고 있으며 재발률이 높기 때문에 예후가 좋지 않으나 빈도가 매우 낮다. 비강내 신경초종은 주로 피 막화 되어있고 단발성이며 서서히 성장하기 때문에 비내시 경을 통한 수술적 제거술의 결과가 매우 좋은 것으로 보고 되고 있다. ${ }^{4,5)}$

접형동 신경초종은 발생한 예가 많지 않기 때문에 진단 및 치료방법과 관련하여 아직까지 확실히 정립된 바가 없으 며, 임상적인 증상이나 영상학적 소견으로는 예측하기 매우 어렵다. 따라서 비내시경을 통한 절제술은 확진을 위한 필수 적인 과정이며 종괴를 제거하는 최소 침습적인 방법이라 생 각된다.

\section{REFERENCES}

1) Hillstrom RP, Zarbo RJ, Jacobs JR. Nerve sheath tumors of the paranasal sinuses; Electron microscopy and histopathologic diagnosis. Otolaryngol Head Neck Surg 1990;102(3):257-63.

2) Ross C, Wright E, Moseley J, Rees R. Massive schwannoma of the nose and paranasal sinuses. South Med J 1988;81(12):1588-91.

3) El-Saggan A, Oloffson J, Krossnes B. Sinonasal schwannoma: two case reports and review of literature. Int Congr Ser 2003;1240:503-7.

4) Khodaei I, Davies E. Schwannoma of the inferior turbinate: case report and review of literature. Radiol Bras 2008;41(3):205-6.

5) Srinivasan V, Deans JA, Nicol A. Sphenoid sinus schwannoma treated by endoscopic excision. J Laryngol Otol 1999;113(5):466-8.

6) Calcaterra TC, Rich R, Ward PW. Neurilemmoma of the sphenoid sinus. Arch Otolaryngol Head Neck Surg 1974;100:383-5.

7) Kodama S, Okamoto T, Suzuki M. Ancient schwannoma of the nasal septum associated with sphenoid sinus mucocele. Auris Nasus Larynx 2010;37(4):522-5.

8) Pasic TR, Makielski K. Nasal schwannoma. Otolaryngol Head Neck Surg 1990;103(6):943-6.

9) Dublin AB, Dedo HH, Bridger WH. Intranasal schwannoma: magnetic resonance and computed tomography appearance. Am J Otolaryngol 1995;16(4):251-4.

10) Shinohara K, Hashimoto K, Yamashita M, Omori K. Schwannoma of the nasal septum removed with endoscopic surgery. Otolaryngol Head Neck Surg 2005;132(6):963-4.

11) Ahsan F, El-Hakim H, Ah-See KW. Unilateral opacification of paranasal sinus CT scans. Otolaryngol Head Neck Surg 2005;133(2):17880.

12) Harnsberger HR, Wiggins RH, Hudgins PA, Michel MA, et al. Diagnostic Imaging Head and Neck. International ed. Salt Lake City, Utah: Amirsys Inc;2004. p.II-2-68-99.

13) Lawson W, Reino AJ. Isolated sphenoid sinus disease: an analysis of 132 cases. Laryngoscope 1997;107(12 Pt 1):1590-5.

14) Friedman A, Batra PS, Fakhri S, Citardi MJ. Isolated sphenoid sinus disease: etiology and management. Otolaryngol Head Neck Surg 2005;133(4):544-50.

15) Dharia A, Karmody CS, Rebeiz EE. Schwannoma of the nasal cavity. Ear Nose Throat J 2007;86(4):230-2. 